\title{
Behaviour of impact- and vibratory-driven piles in stiff clay during installation and static loading
}

\author{
*F. Rocher-Lacoste ${ }^{l}$ and M. P. Bourdouxhe ${ }^{2}$ \\ ${ }^{1}$ Laboratoire Central des Ponts et Chaussées, Paris, France \\ ${ }^{2}$ PROFILARBED S. A., Arcelor Group, Luxembourg \\ (*Email: frederic.rocher.lacoste@lcpc.fr)
}

\begin{abstract}
This paper summarises the results of an extensive field test carried out in the framework of the "French National Research Project on Vibratory Driving" and the ProfilArbed Research Programme, to investigate and compare the behaviour and performance of eight impact- and vibratory-driven piles. The test site is located in Northern France. The subsoil consists of dense Flanders clay. The piles were driven using an ICE815 vibrator and an IHC70s impact hammer to the same depth. All these piles were instrumented with accelerometers and strain gauges positioned at the top and bottom of the piles. Penetration rate, uplift load applied by the crane, vibration transmitted to the ground, operating pressure, oil flow at the vibratory power-pack, and energy per blow for the hammer were continuously recorded. The paper presents the main results obtained from double sheet piles (AU16 type) driven to $7 \mathrm{~m}$ depth, a small wall of two double sheet piles (AU20 type) driven to $8 \mathrm{~m}$ depth, HP bearing piles driven to $10.2 \mathrm{~m}$, and steel open-ended tubes of $508 \mathrm{~mm}$ diameter driven to 9.4 $\mathrm{m}$ depth. After a delay of 6 to 8 weeks, the piles were statically loaded to failure. The piles were instrumented with removable extensometers, which made it possible to measure the mobilisation of shaft friction and toe resistance. The measured bearing capacity was significantly lower for the vibratory-driven piles (around 35\%) and it is consistent with the results obtained by the Laboratoire des Ponts et Chaussées de Paris at other sites.
\end{abstract}

\section{INTRODUCTION}

At the airfield of Merville, Northern France, the Laboratoire des Ponts et Chaussées de Paris (LPCP) has established a research site since last thirty years. In the framework of the "French National Research Project on Vibratory Driving" and ProfilArbed S. A., it was decided to select the Merville site in order to study the behaviour of the dense Flanders clay during static loading by driving various steel piles. The field site is flat and easily accessible.

To carry out the study, it was decided to reuse an reaction system consisting of three pairs of L2S type sheet piles impact driven to $16 \mathrm{~m}$. For this purpose, six pairs of sheet piles (AU16 type and AU20 type), two HP-bearing piles (HP400*213), and two open-ended steel tubes of $508 \mathrm{~mm}$ diameter were installed between March and April 2003 (Fig. 1). All these piles were instrumentally monitored.

In order to drive the vibratory piles into the dense Flanders clay an additional mass with the ICE815 vibrator (Table 1) had to be used.

It was decided to test a new steel pile (AU type) from ProfilArbed S. A. and a new IHC anvil for the AU steel pile (Table 1). To carry out the static loading test, it was necessary to install two new reaction walls. The first was made out of five pairs of sheet piles (PU16 type) while the second contained four pairs of sheet piles (AU16 type). All the steel piles were installed from $0 \mathrm{~m}$ to around $7.5 \mathrm{~m}$ depth with the
ICE815 vibrator (Fig. 2) and from 7.5 to $12.75 \mathrm{~m}$ depth with the IHC70s hammer (Fig. 3).

\section{SITE INVESTIGATION}

The Flanders clay is a marine clay deposit of Ypresian (early Eocene) age. The total thickness of the original formation is greater than $250 \mathrm{~m}$. Subsequent erosion has removed this formation to leave a typical layer of $40 \mathrm{~m}$ thickness (Fig. 4).

The natural soils encountered are quite uniform over the whole site of Merville. The near-surface soil, up to a $2.2 \mathrm{~m}$ depth, consists of silt with about $50 \mathrm{~cm}$ thick hardened crust due to humidification and desiccation cycles. The Flanders clay is then found up to a $42 \mathrm{~m}$ depth. Its geotechnical properties vary linearly with depth.

The water table in the silty clay layer fluctuates frequently between 1.5 and $1.9 \mathrm{~m}$ below ground, depending on the season and amount of rainfall. It is difficult to establish a water table in the Flanders clay, a very impermeable soil with a strongly micro-cracked structure. The ground level is located at an altitude of $17.8 \mathrm{~m}$. The stratigraphic subdivisions in the study area are as follows.

- From 0 to about $2.2 \mathrm{~m}$ depth: low-plasticity silt affected by water table fluctuations;

- From $2.2 \mathrm{~m}$ to $42 \mathrm{~m}$ depth: Flanders clay of 
Rocher-Lacoste and Bourdouxhe

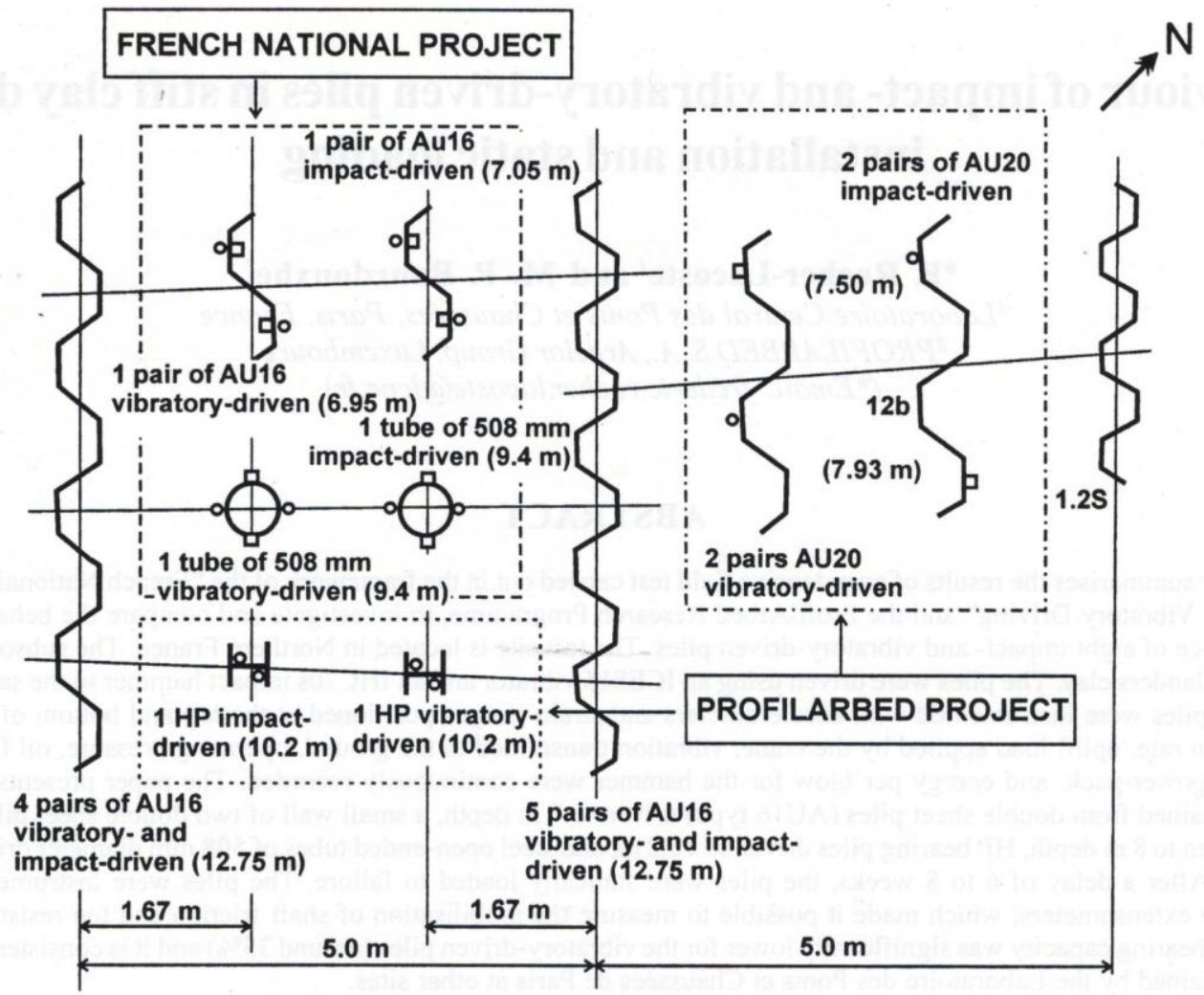

Fig. 1: General layout of the site

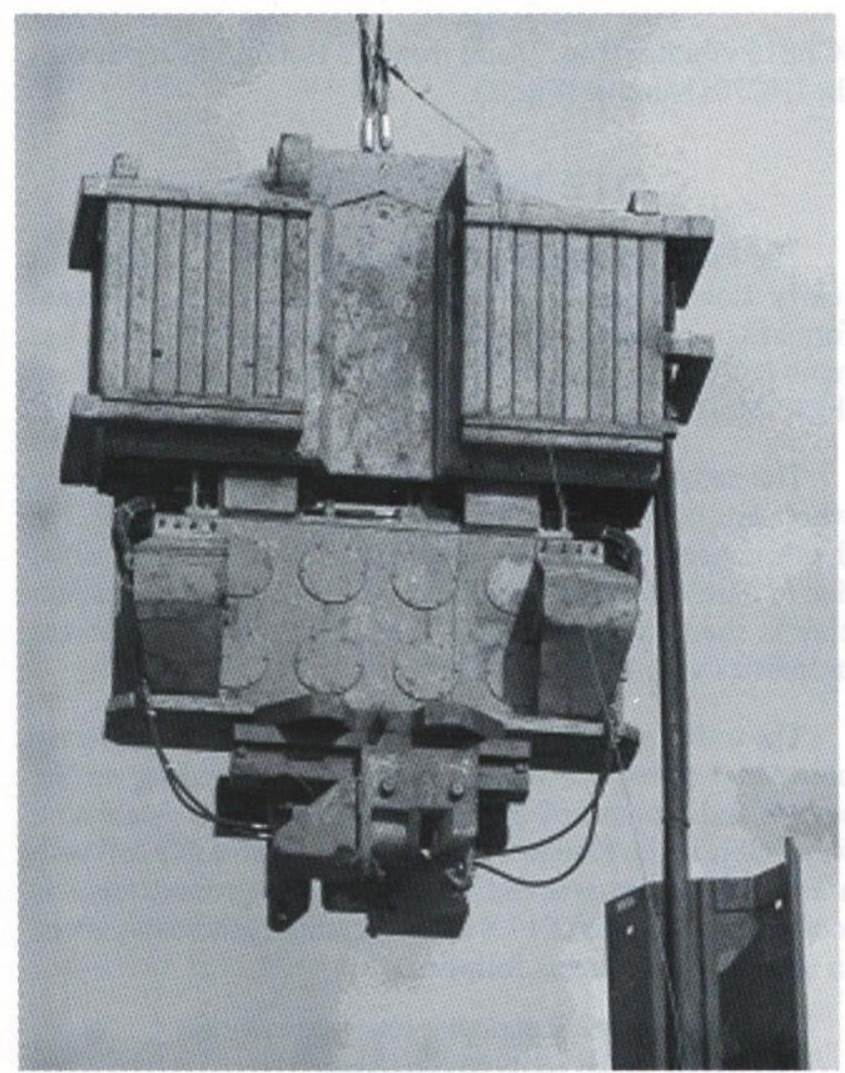

Fig.2: ICE815 vibrator with the additional mass

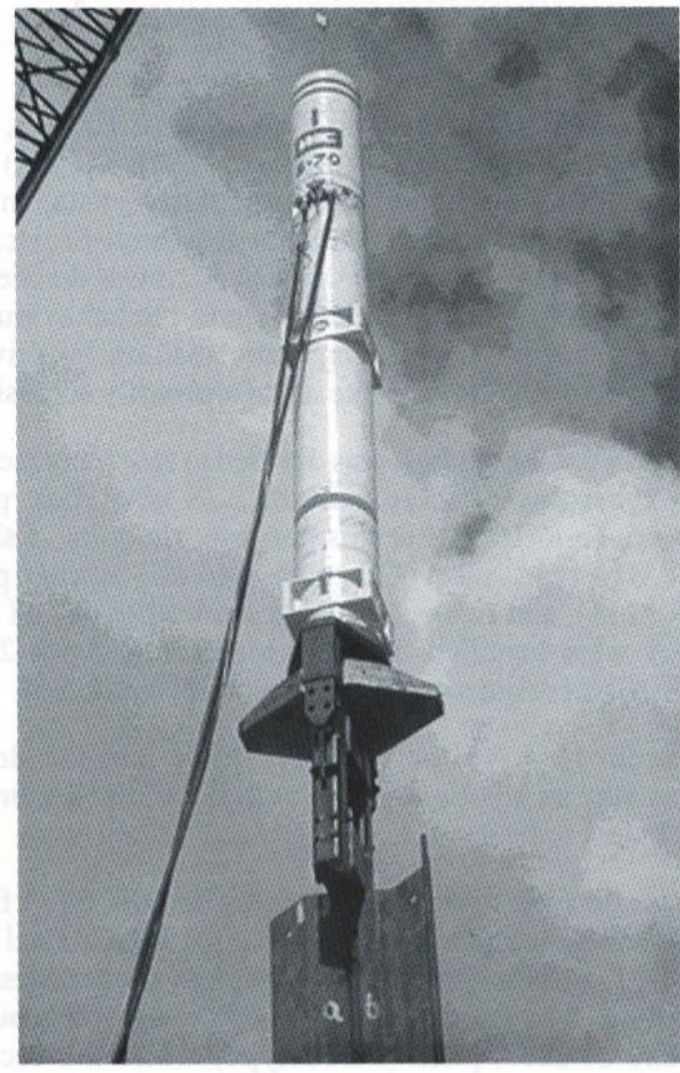

Fig. 3: IHC 70s hammer with the new AU anvil 


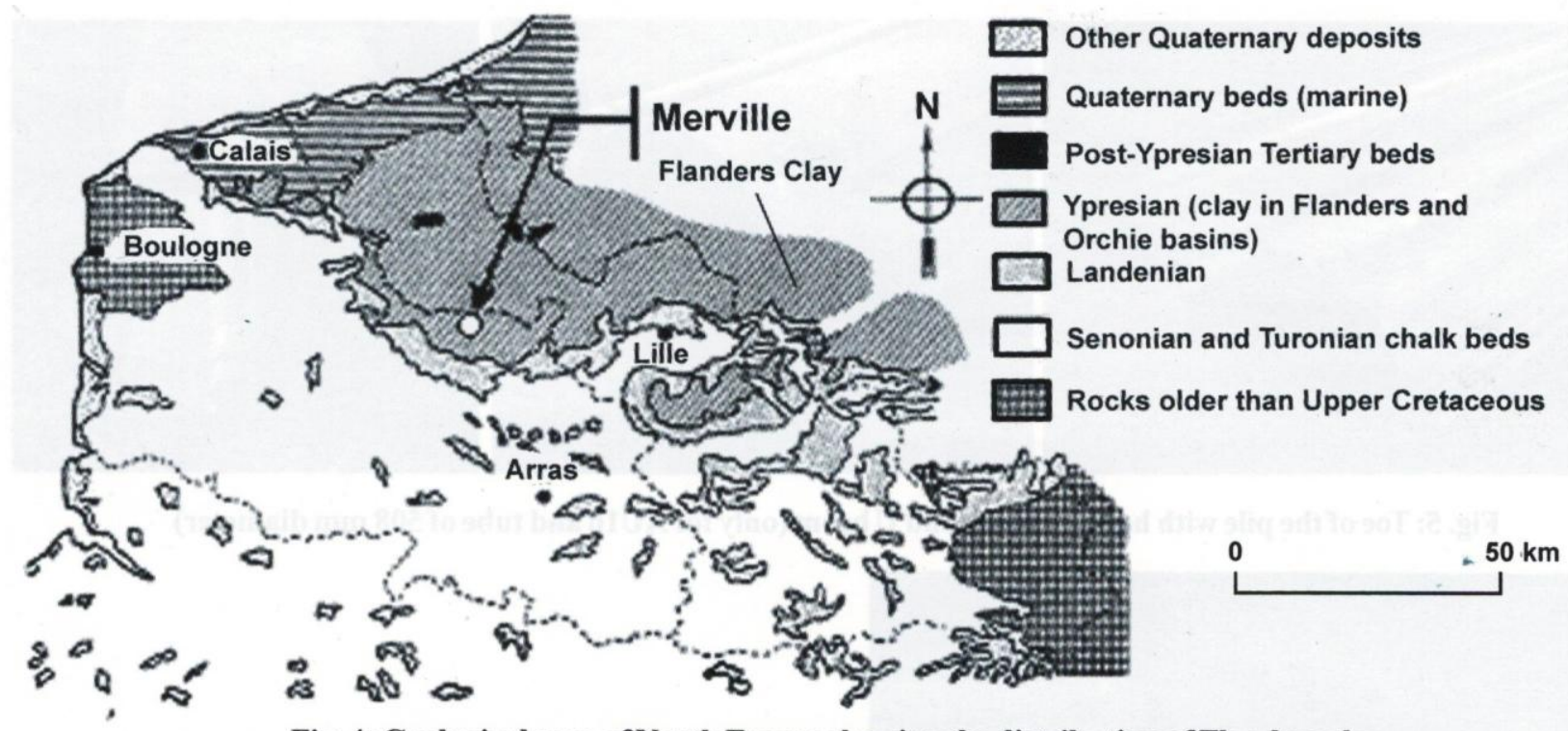

Fig. 4: Geological map of North France showing the distribution of Flanders clay

Table 1: ICE 815 and IHC 70s main characteristics

\begin{tabular}{l|l|l|l}
\hline \multicolumn{2}{c|}{ ICE 815 vibrator } & \multicolumn{2}{c}{ IHC 70s hammer } \\
\hline Maximum frequency & $26 \mathrm{~Hz}$ & Ram weight & $3500 \mathrm{~kg}$ \\
\hline Eccentric moment & $46 \mathrm{~kg} . \mathrm{m}$ & Maximum blow rate & $50 \mathrm{blow} / \mathrm{min}$ \\
\hline Centrifugal force & $1250 \mathrm{kN}$ & Max. energy per blow & $70 \mathrm{kN} . \mathrm{m}$ \\
\hline Maximum amplitude & $26 \mathrm{~mm}$ & Min. energy per blow & $2 \mathrm{kN} . \mathrm{m}$ \\
\hline Vibrating weight (without clamps) & $3550 \mathrm{~kg}$ & Total weight (for AU) & $10910 \mathrm{~kg}$ \\
\hline Additional weight & $4000 \mathrm{~kg}$ & Total weight (for Ø $508 \mathrm{~mm}$ ) & $10390 \mathrm{~kg}$ \\
\hline Total weight (for AU) & $12110 \mathrm{~kg}$ & Total weight (for HP) & $11660 \mathrm{~kg}$ \\
\hline Total weight (for Ø $508 \mathrm{~mm}$ ) & $11360 \mathrm{~kg}$ & \multicolumn{1}{|l}{} \\
\cline { 1 - 2 } Total weight (for HP) & $10950 \mathrm{~kg}$ & &
\end{tabular}

Ypresian age;

- From $42 \mathrm{~m}$ to $84 \mathrm{~m}$ : Landenian sand and clay horizons;

- Below $84 \mathrm{~m}$ : Senonian and Turonian chalk bed.

The penetrometer test (PMT) and standard penetration test (SPT) results are given in Table 2.

\section{INSTRUMENTATION OF PILES}

In both cases of vibratory and impact driving, the piles were monitored with a continuous record of:

- penetration rate,

- acceleration and stresses at the top and at the pile toe,

- vibration transmitted to the ground,

- uplift load applied by the crane (only in case of vibratory driving),

- oil pressure and the outflow from vibratory power pack, and

- energy per blow and blow count of the impact driver.

Two additional steel tubes were welded to receive the signals from the LPC removable extensometers during the static loading test (Bustamante and Doix 1991). Two extra steel U-beams were also welded to the opposite ends to receive the records of accelerometers and strain gauges from the toe. The positions of various accessories are shown in Fig. 5.
Table 2: Geotechnical results

\begin{tabular}{l|c|c}
\hline & Pl* $^{*}$ Mpa) & qc $($ Mpa) \\
\hline Silt (0 to $2.2 \mathrm{~m})$ & 0.25 to & 1 \\
\hline Flanders clay (at $4 \mathrm{~m})$ & 0.75 & 2 \\
\hline Flanders clay (at $16 \mathrm{~m})$ & 1.8 & 5 \\
\hline
\end{tabular}

\section{OBSERVATION DURING INSTALLATION}

The first batch of piles was vibratory driven (Fig. 6) and the second one was impact driven. We present only the observations on the AU16 type sheet piles and the openended steel tubes.

\section{Vibratory driving}

An AU16 type of sheet pile was vibratory driven to a depth of $6.95 \mathrm{~m}$ on 2 April 2003 in 31 minutes. The toe accelerometers recorded the vibration at an interval of 30 minutes. The open-ended steel tubes of $508 \mathrm{~mm}$ diameter were vibratory driven to a depth of $9.40 \mathrm{~m}$ on 7 April 2003 in 44 minutes.

The driving records of the sheet pile and open-ended tube are shown in Figs. 7 and 8 respectively. During vibratory driving, the penetration rate reached a maximum of around 


\section{Rocher-Lacoste and Bourdouxhe}
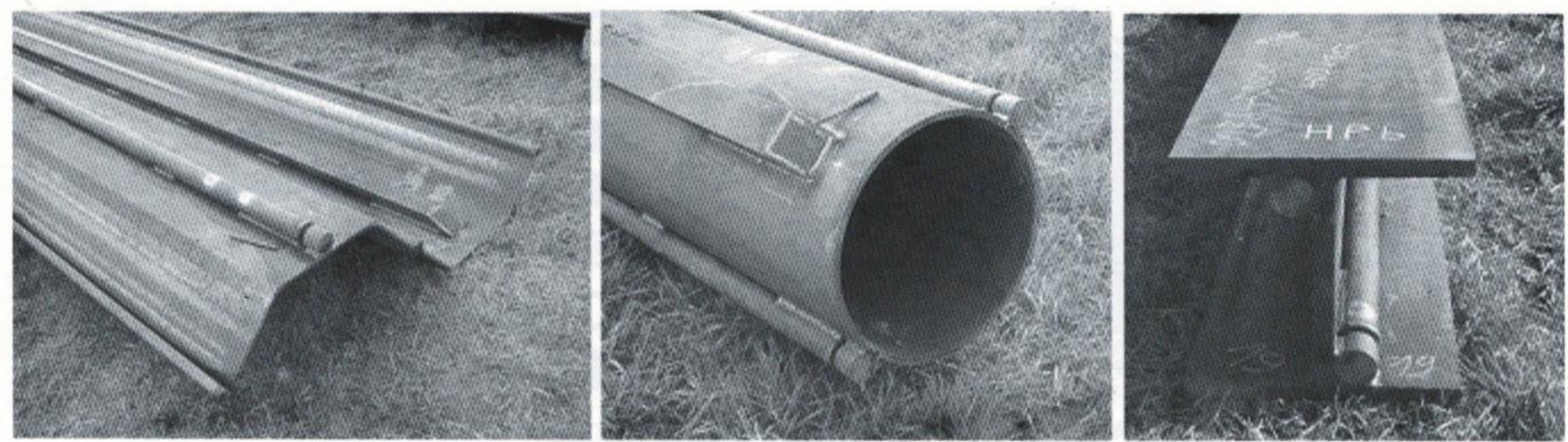

Fig. 5: Toe of the pile with housing tubes and U beam (only for AU16 and tube of $508 \mathrm{~mm}$ diameter)

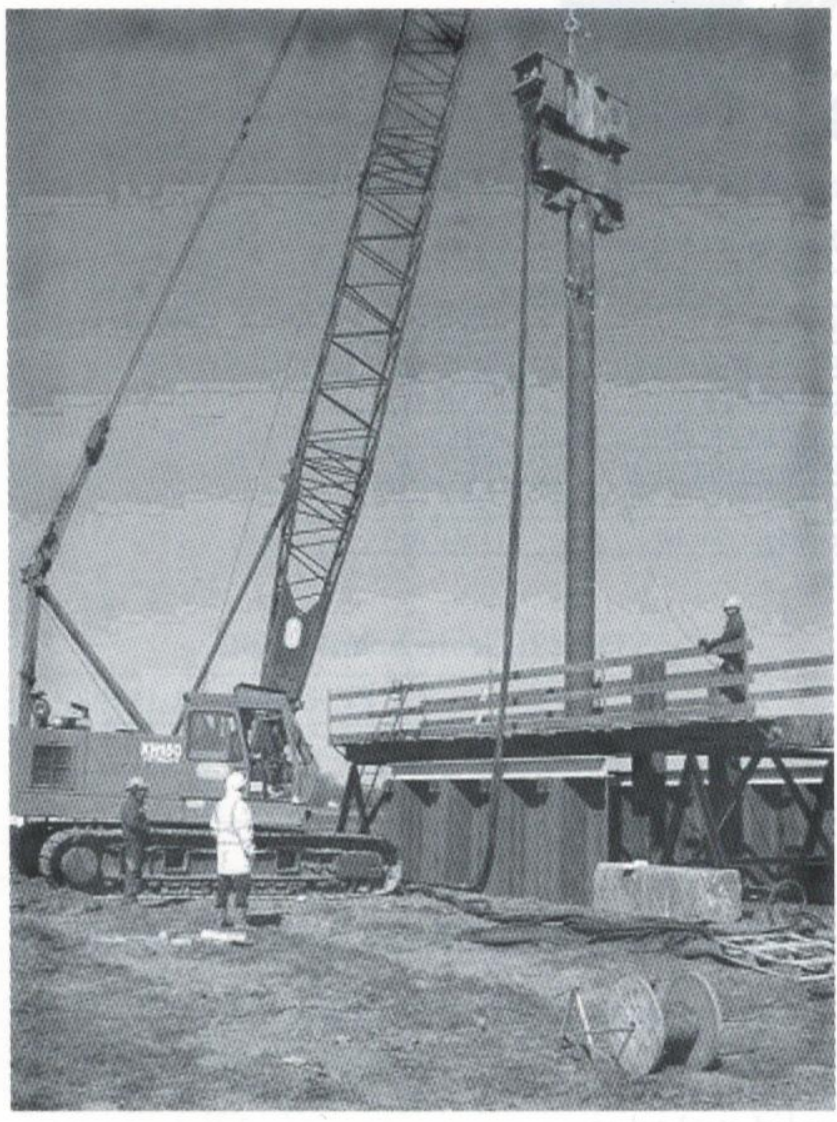

Fig. 6: Driving the pile

$1.4 \mathrm{~m} / \mathrm{min}$ between 0 and $4 \mathrm{~m}$ depths. Between 4 and $5 \mathrm{~m}$ depths, the penetration speed rapidly decreased to $20 \mathrm{~cm} /$ $\mathrm{min}$. At the end, the penetration rate was only $10 \mathrm{~cm} / \mathrm{min}$, close to the refusal value of $5 \mathrm{~cm} / \mathrm{min}$.

The uplift load applied by the crane is shown in Fig. 9. When the penetration rate started to decrease, the uplift also decreased. The crane operator just maintained the uniform load (around $10 \mathrm{kN}$ ) of the ICE815 vibrator.

It was possible to measure the working frequency (Fig. 10) of the ICE815 vibrator with the help of a connected
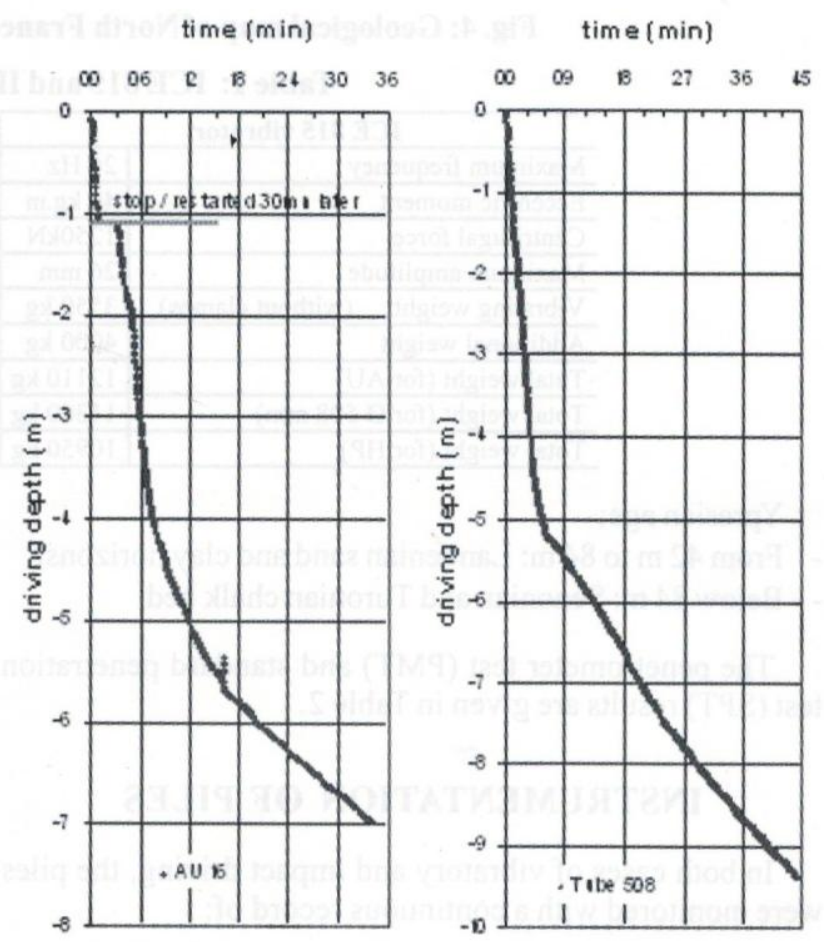

Fig. 7: Vibratory driving records of sheet piles and tubes

sensor. At a depth of about $4 \mathrm{~m}$, the pile was into the Flanders clay with a limiting pressure of $0.75 \mathrm{MPa}$. During the vibratory driving, the frequency decreased from 25 to $19 \mathrm{~Hz}$ at the end of the penetration. At the same time, the penetration rate also decreased.

When the penetration was stopped, a decrease of $25 \%$ in the frequency between the beginning and the end of vibratory driving was observed. 


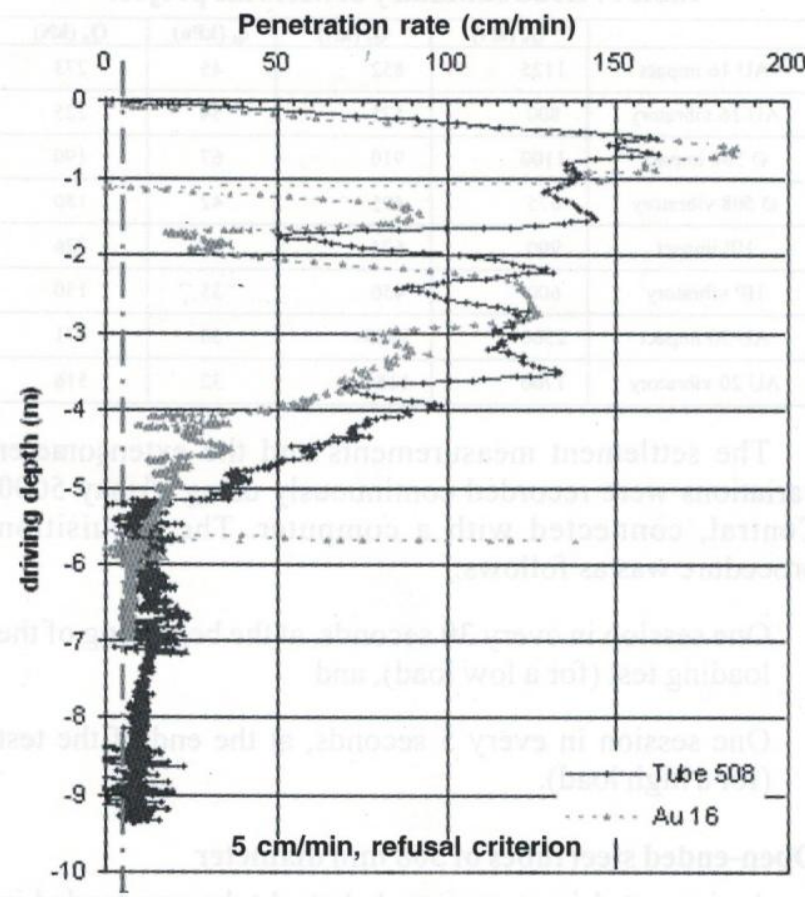

Fig. 8: Penetration rate of vibratory driving

200

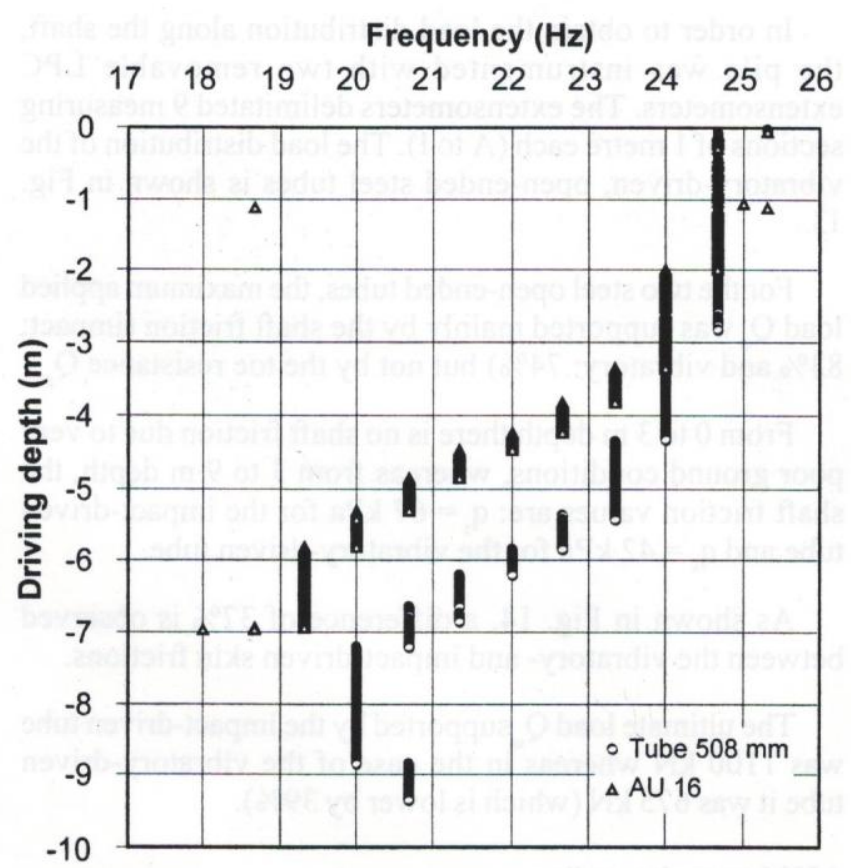

Fig. 10: Plot of driving depth against vibration frequency for tubes and piles
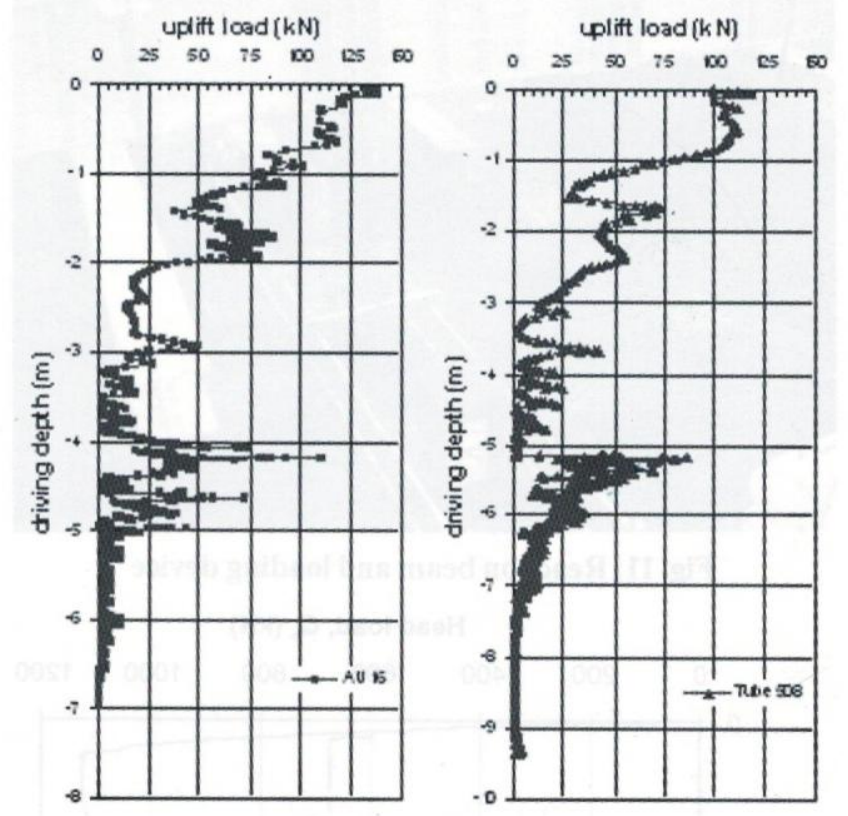

Fig. 9: Uplift load of the crane

\section{Impact driving}

The AU16-type sheet pile was impact driven on 3 April 2003 to a $7.05 \mathrm{~m}$ depth in 13 minutes. The steel open-ended tube of $508 \mathrm{~mm}$ diameter was impact driven on 8 April 2003 to a depth of $9.40 \mathrm{~m}$ in 15 minutes. It is necessary to add to this time the vibratory driving installation time of the pile from 00 to $1.5 \mathrm{~m}$.

The IHC S70 hammer was operated with the following procedure:

- Driving was started at an energy level of $10 \mathrm{kNm}$.

- When the penetration rate was lower than $25 \mathrm{~cm}$ for 40 blows, the energy level was increased to $20 \mathrm{kNm}$.

- The driving was repeated until a maximum energy level of $70 \mathrm{kNm}$ was reached.

The rise of the energy level from 10 to $20 \mathrm{kNm}$ was observed at a $5 \mathrm{~m}$ penetration depth for the AU16-type sheet pile and at a $7 \mathrm{~m}$ penetration depth for the open-ended steel tube of $508 \mathrm{~mm}$ diameter.

The refusal limit was not reached with the impact-driving method because the impact penetration was stopped at the vibratory-driving level. A target of this project was to study the behaviour of two similar piles installed with the two different methods.

\section{STATIC LOADING TEST}

The piles were loaded in compression to failure, according to the Maintained Load procedure. Each loading 


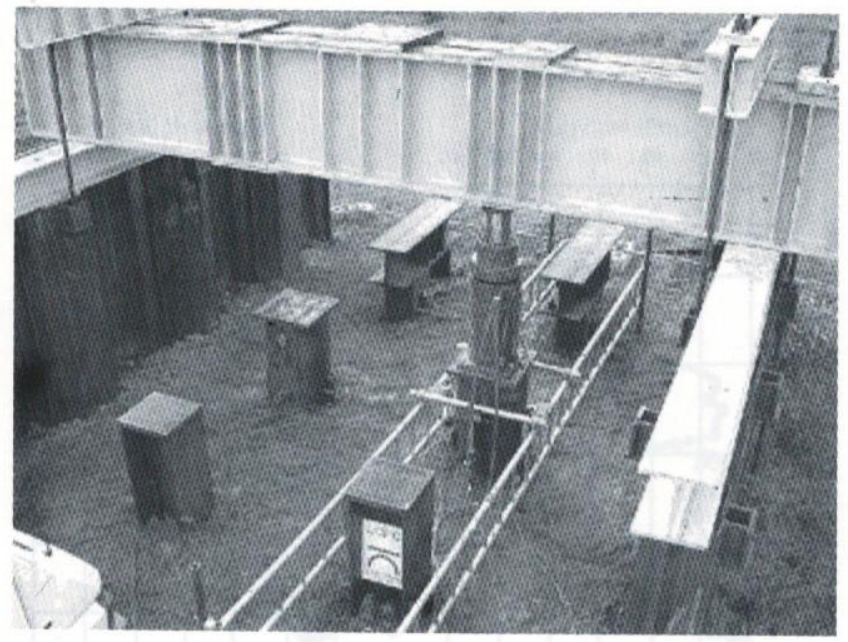

Fig. 11: Reaction beam and loading device

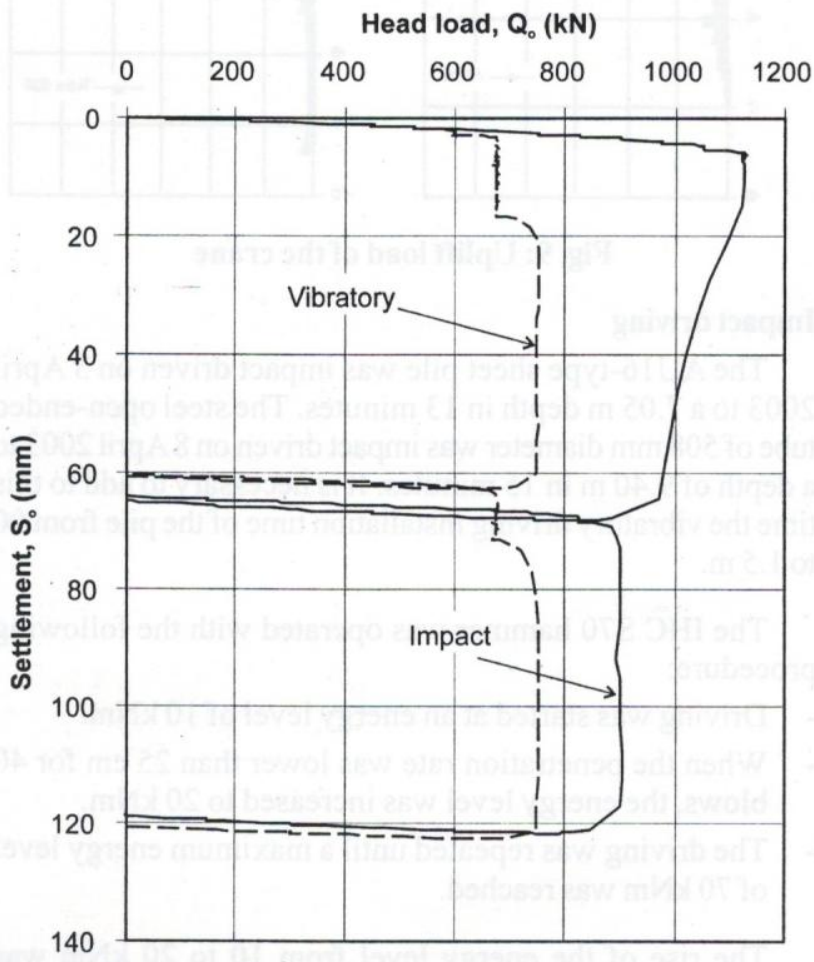

Fig. 12: Load-settlement curves for open-ended steel tubes

step was applied for 30 minutes. The load was checked with a $2500 \mathrm{kN}$ loading cell and the displacement was measured with 4 linear potentiometers linked to reference beams. The loading frame consisted of a reaction beam supported by 2 reaction sheet walls (Fig. 11).

All the piles were instrumented with removable LPC extensometers, which recorded the load distribution along the shaft and at the base. The extensometers defined 7 measuring sections on the sheet piles of AU type, 9 sections on the open-ended steel tubes, and 10 on the HP-bearing piles.
Table 3: Load summary of Merville project

\begin{tabular}{c|c|c|c|c}
\hline & $\mathbf{Q}_{\mathrm{u}}(\mathbf{k N})$ & $\mathbf{Q}_{\mathbf{s}}(\mathbf{k N})$ & $\mathbf{q}_{\mathbf{s}}(\mathbf{k P a})$ & $\mathbf{Q}_{\mathrm{p}}(\mathbf{k N})$ \\
\hline AU 16 impact & 1125 & 852 & 45 & 273 \\
\hline AU 16 vibratory & 800 & 575 & 34 & 225 \\
\hline Ø 508 impact & 1100 & 910 & 67 & 190 \\
\hline Ø 508 vibratory & 675 & 495 & 42 & 180 \\
\hline HP impact & 900 & 674 & 50 & 226 \\
\hline HP vibratory & 600 & 450 & 35 & 150 \\
\hline AU 20 impact & 2500 & 1829 & 50 & 671 \\
\hline AU 20 vibratory & 1700 & 1184 & 32 & 516 \\
\hline
\end{tabular}

The settlement measurements and the extensometer variations were recorded continuously using Vishay 5000 Central, connected with a computer. The acquisition procedure was as follows:

- One session in every 30 seconds, at the beginning of the loading test (for a low load), and

- One session in every 5 seconds, at the end of the test (for a high load).

\section{Open-ended steel tubes of $508 \mathrm{~mm}$ diameter}

An impact-driven open-ended steel tube was loaded in compression on 22 May 2003 after a delay of 44 days while the other one was vibratory driven on 3 June 2003 after a delay of 57 days. Their load settlement curves are shown in Fig. 12. The ultimate resistance (i.e. the load for which the pile head movement exceeds $10 \%$ of the tube diameter) is presented in Table 3.

In order to obtain the load distribution along the shaft, the pile was instrumented with two removable LPC extensometers. The extensometers delimitated 9 measuring sections of 1 metre each (A to I). The load distribution of the vibratory-driven, open-ended steel tubes is shown in Fig. 13.

For the two steel open-ended tubes, the maximum applied load $\mathrm{Q}_{\mathrm{u}}$ was supported mainly by the shaft friction (impact: $83 \%$ and vibratory: $74 \%$ ) but not by the toe resistance $Q_{p}$.

From 0 to $3 \mathrm{~m}$ depth there is no shaft friction due to very poor ground conditions, whereas from 3 to $9 \mathrm{~m}$ depth, the shaft friction values are: $q_{s}=67 \mathrm{kPa}$ for the impact-driven tube and $\mathrm{q}_{\mathrm{s}}=42 \mathrm{kPa}$ for the vibratory-driven tube.

As shown in Fig. 14, a difference of $37 \%$ is observed between the vibratory- and impact-driven skin frictions.

The ultimate load $\mathrm{Q}$ supported by the impact-driven tube was $1100 \mathrm{kN}$ whereas in the case of the vibratory-driven tube it was $675 \mathrm{kN}$ (which is lower by $39 \%$ ).

\section{AU16 type sheet piles}

Compressive loads were applied to an AU16 type impactdriven sheet pile on 20 May after 46 days of delay and to 

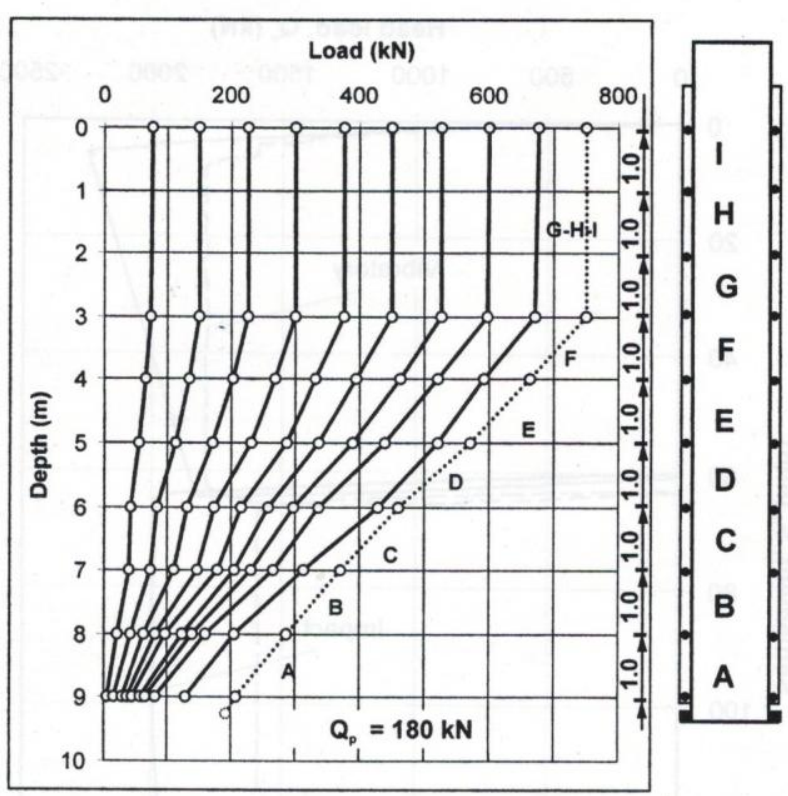

Fig. 13: Plot of load distribution versus depth for the vibratory-driven open-ended steel tubes

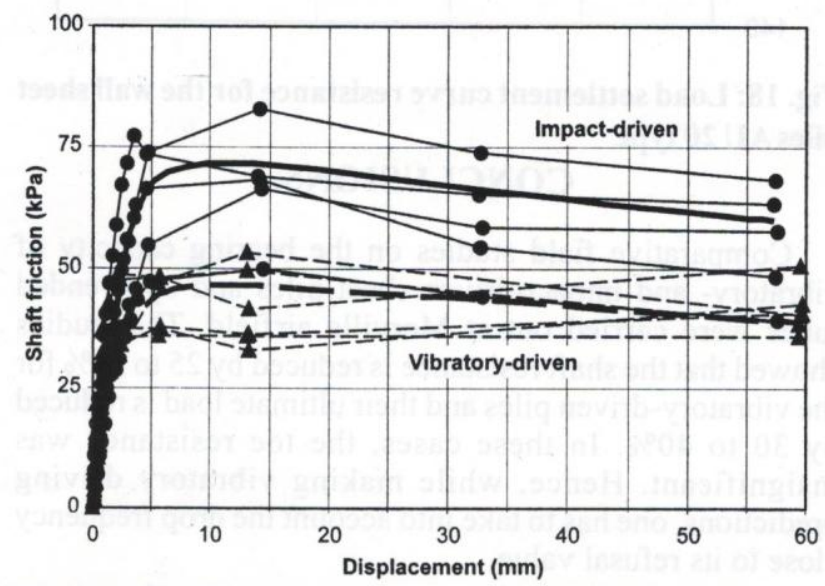

Fig. 14: Mobilisation of shaft resistance along the steel open-ended tubes of $508 \mathrm{~mm}$ diameter

another AU16 type vibratory-driven sheet pile on 21 May 2003 after 48 days of delay.

The plots of settlement versus load for the AU16 type sheet piles are shown in Fig. 15. The ultimate resisting load for which the pile head movement exceeds $10 \%$ of the diameter, is presented in Table 3. The ultimate load $\mathrm{Q}_{4}$ supported by the impact-driven sheet pile was $1125 \mathrm{kN}$ and it was $800 \mathrm{kN}$ (i.e. $30 \%$ less) for the vibratory-driven sheet.

For the two sheet piles of AU16 type, the maximum applied load $\mathrm{Q}_{u}(75 \%)$ was supported mainly by the shaft friction and the toe resistance $Q_{p}(25 \%)$ played only a minor role. No shaft friction is recorded from 0 to $3 \mathrm{~m}$ depth because of the very poor ground. From 3 to $7 \mathrm{~m}$ depth, the shaft friction values are: $q_{\mathrm{s}}=45 \mathrm{kPa}$ for the impact driven AU16 sheet pile and $q_{s}=34 \mathrm{kPa}$ for the vibratory-driver Aul6 sheet pile.

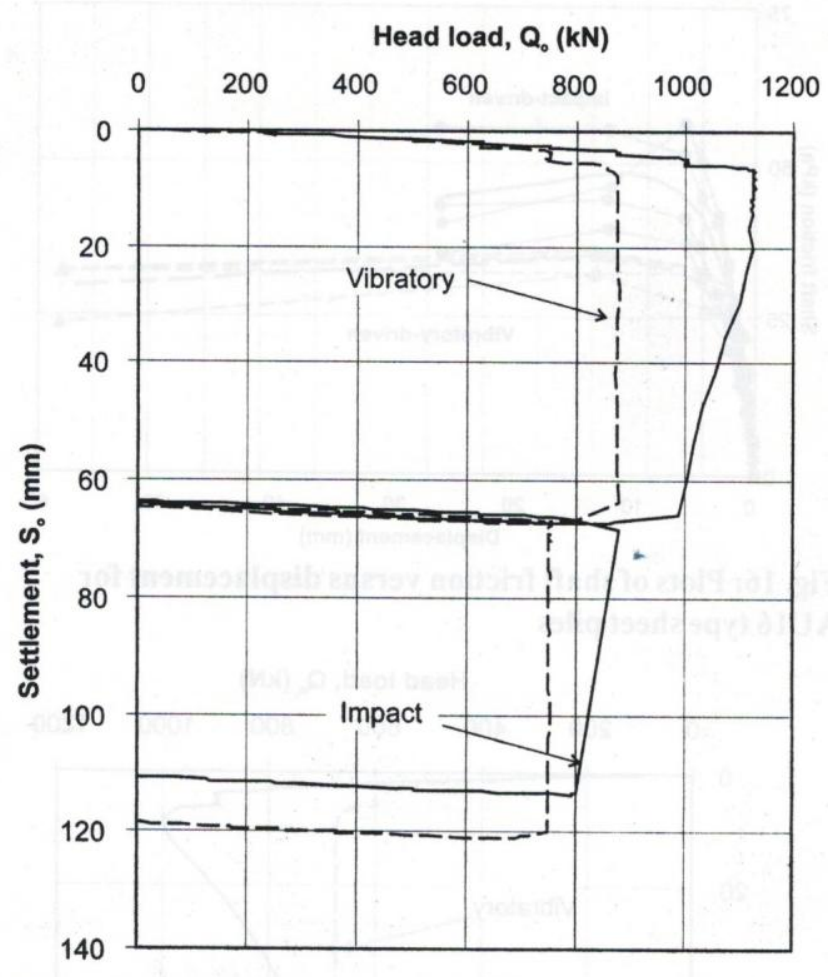

Fig. 15: Plots of settlement against load for AU16 type sheet piles

As shown in Fig. 16, a difference of $25 \%$ between the vibratory- and impact-driven skin frictions is observed.

\section{HP-bearing piles}

An impact driven HP-bearing pile was loaded in compression on 4 June 2003 after a delay of 60 days and another HP-bearing pile was vibratory driven on 3 June 2003 after a delay of 62 days. Their load-settlement curves are shown in Fig. 17 and the ultimate resistance is presented in Table 3.

The ultimate loads $\mathrm{Q}_{u}$ supported by the impact-driven HP pile and vibratory-driven sheet were $900 \mathrm{kN}$ and $600 \mathrm{kN}$ (i.e. $33 \%$ less) respectively. As in the case of AU16 type sheet piles, for the two HP piles, the maximum applied load $\mathrm{Q}_{\mathrm{u}}(75 \%)$ was supported mainly by the shaft friction and the toe resistance $Q_{p}(25 \%)$ played a minor role. From 0 to $3 \mathrm{~m}$ depth there is no shaft friction because of very poor ground conditions. The shaft friction values from 3 to $10 \mathrm{~m}$ depth are: $q_{s}=50 \mathrm{kPa}$ for the impact-driven $\mathrm{HP}$ and $\mathrm{q}_{\mathrm{s}}=35 \mathrm{kPa}$ for the vibratory-driven HP.

\section{AU 20 type sheet piles}

The AU20-type impact-driven sheet piles were loaded in compression on 11 June 2003 after a delay of 74 days and similar other sheet piles were vibratory driven on 12 June 2003 after 76 days of delay. Their load settlement curves are shown in Fig. 18 whereas the ultimate resistance is presented in Table 3. The ultimate loads $Q_{u}$ supported by the impact- 


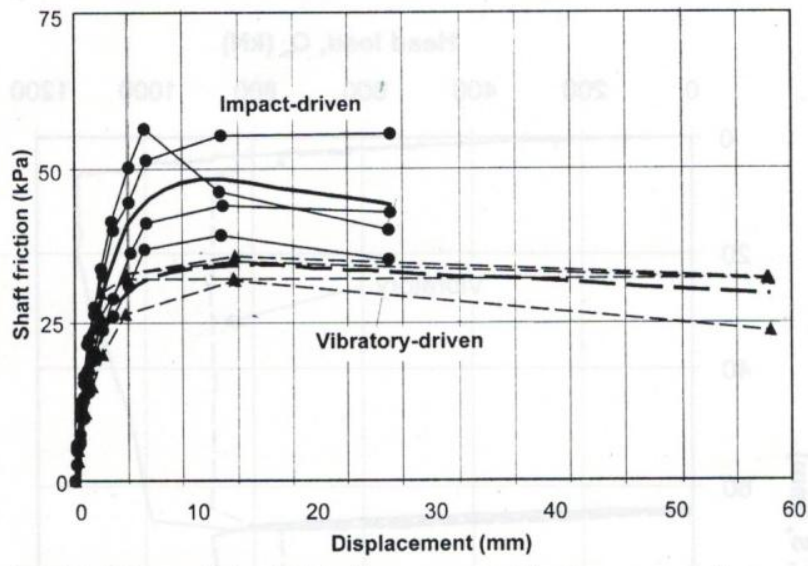

Fig. 16: Plots of shaft friction versus displacement for AU16 type sheet piles

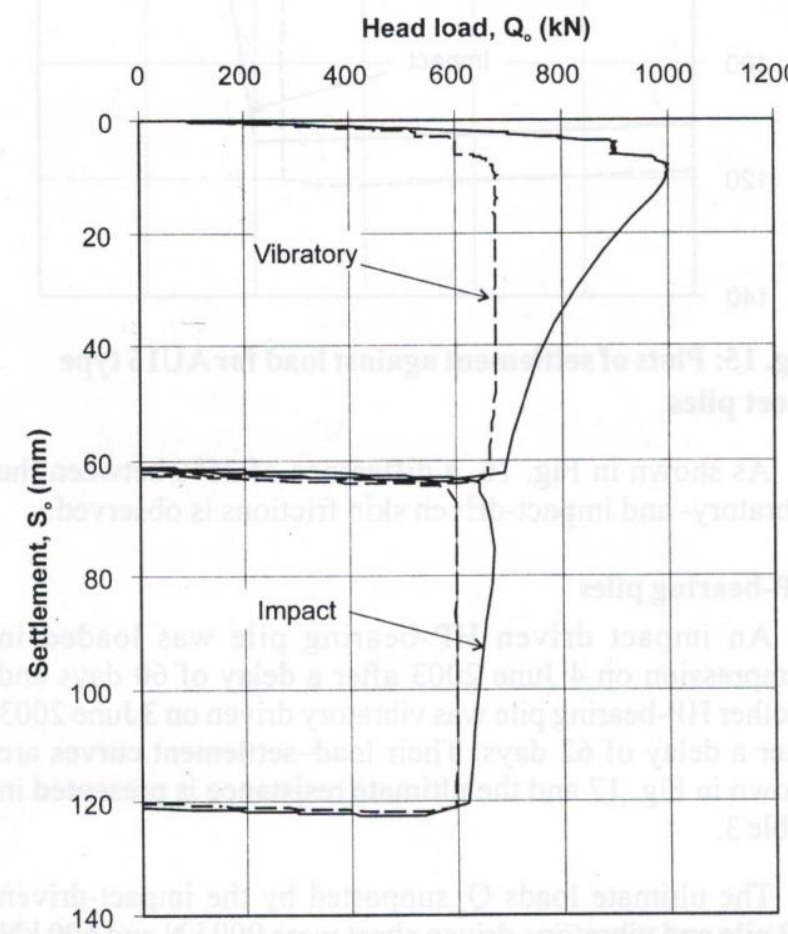

Fig. 17: Plots of settlement against load for HP-bearing piles

driven sheet piles and the vibratory-driven sheets were 2500 $\mathrm{kN}$ and $1700 \mathrm{kN}$ (i.e. $32 \%$ less) respectively.

For the two pairs of AU20 sheet piles, the maximum applied load $\mathrm{Q}_{u}$ was supported mainly by the shaft friction $(70 \%)$ and not by the toe resistance $Q_{p}(30 \%)$. From 0 to $3 \mathrm{~m}$ there is no shaft friction, because of very poor ground conditions. From 3 to $8 \mathrm{~m}$ depth, the shaft friction values are: $\mathrm{q}_{\mathrm{s}}=50 \mathrm{kPa}$ for the impact-driven AU 20 piles and $\mathrm{q}_{\mathrm{s}}=32 \mathrm{kPa}$ for the vibratory-driven AU20 piles.

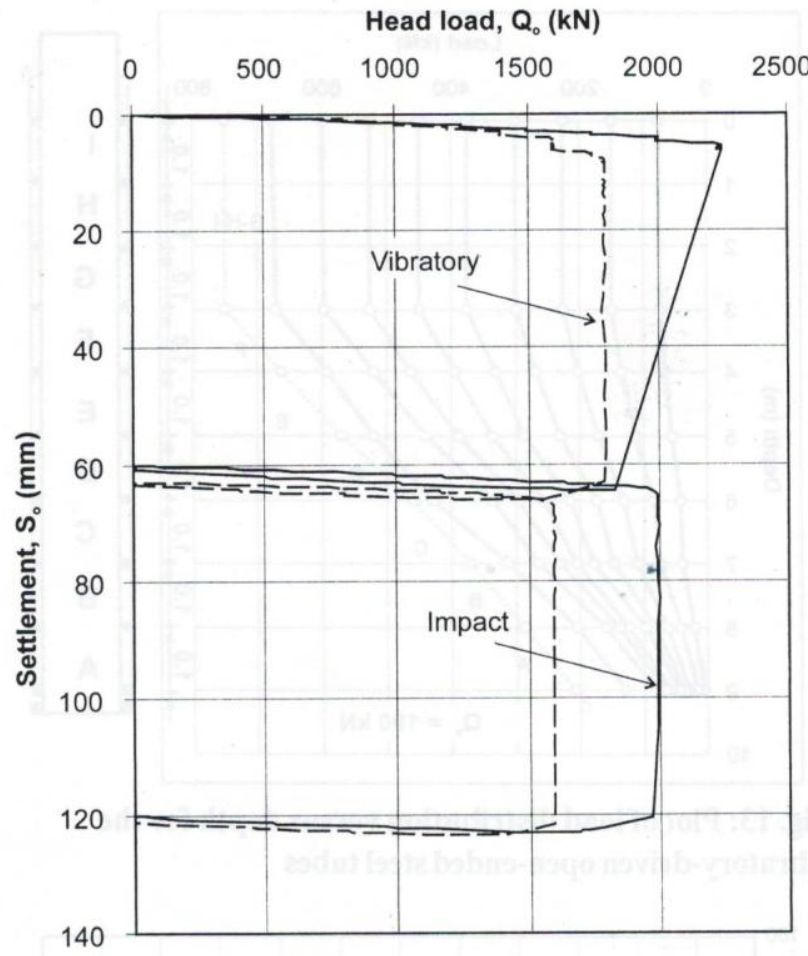

Fig. 18: Load settlement curve resistance for the wall sheet piles AU 20 type

\section{CONCLUSIONS}

Comparative field studies on the bearing capacity of vibratory- and impact-driven sheet piles and open-ended tubes were carried out at Merville airfield. The studies showed that the shaft resistance is reduced by 25 to $35 \%$ for the vibratory-driven piles and their ultimate load is reduced by 30 to $40 \%$. In these cases, the toe resistance was insignificant. Hence, while making vibratory driving predictions, one has to take into account the drop frequency close to its refusal value.

\section{ACKNOWLEDGEMENTS}

The tests reported in this paper were carried out in the framework of the French National Project on vibratory driving. The French Ministry of Public Works and the ProfilArbed S. A. (Arcelor Group) Company are acknowledged for their financial and technical support. The authors wish to thank the "Laboratoire Régional de Ponts et Chaussées de Lille" and ICE-IHC Company for their technical support. The authors are especially grateful to NORPAC Company for its excellent performance and to Pierre Teixeira for the quality of his work.

\section{REFERENCE}

Bustamante, M. and Doix, B. 1991, A new model of LCP removable extensometer. Proceedings of 4th International Conference on Piling and Deep Foundation. Stresa. 7-12 April 1991, Rotterdam: Balkema. 